\title{
Negative Agenda Control in the Senate and House: Fingerprints of Majority Party Power
}

\author{
Sean Gailmard University of California, Berkeley \\ Jeffery A. Jenkins University of Virginia
}

\begin{abstract}
We present evidence suggesting that the majority party in the U.S. Senate exercises significant negative agenda control. Furthermore, this majority party negative agenda control in the Senate is very similar, in empirical terms, to negative agenda control exercised by the majority party in the U.S. House of Representatives. This evidence comes from comparisons of majority party roll rates across legislative vehicles ( $S$ bills, confirmation votes, and conference reports) and across chambers of Congress. Majority party roll rates respond to disagreement with other political actors as if the Senate majority party does restrict agenda access. Moreover, the response of majority party roll rates to disagreement with other political actors is very similar across the two chambers. Given that explanations of majority party negative agenda control in the House are often predicated on chamber-specific factors with no clear analogues in the Senate, the results reveal a striking cross-chamber similarity.
\end{abstract}

$\mathrm{T}$ he stakes of the role and power of political parties in the U.S. Congress are vast. Powerful parties would structure the evaluation of Congress for voters and provide avenues of accountability in electoral institutions, affect the career paths of legislators, and define prospects for policy change and the content of new policy in the United States. Understanding the extent and channels of party power, then, is crucial for understanding policymaking and accountability in the United States.

Examinations of the power of parties-ingovernment generally focus on the U.S. House of Representatives (Aldrich 1995; Cox and McCubbins 1993, 2005; Rohde 1991). As a result, the nature and institutional underpinnings of party power are typically connected to features most prominent in or unique to the House, and absent or less apparent in the Senate. The Rules Committee and the Speakership are the two most prominent examples. These institutions are controlled in the modern House by the majority party, and they (along with committee and subcommittee chairmen) jointly exert tight control over the agenda of the body. In particular, they make it possible to keep bills opposed by a majority of the majority party from receiving floor consideration in the House, thus protecting the entrenched set of status quo policies. This notion of the majority party in the House operating as a procedural cartel to exercise negative agenda control is most thoroughly explicated by Cox and McCubbins $(2002,2005){ }^{1}$

The U.S. Senate, however, lacks these same institutions or any close relatives. Instead, unanimous consent dominates the popular understanding of Senate floor procedure (Oleszek 2004). The majority leader in the Senate has some scheduling power but (at least on the equilibrium path) confers with the minority leader in using it. Most importantly for comparisons of agenda setting, the Senate has much less control than the House over what issues are raised and considered by the body. In the modern Senate, a Senator needs no special clearance to raise most any policy issue at most any time, via a nongermane amendment. Moreover, for most legislative vehicles a supermajority must agree before debate on any issue, else it can be ended by parliamentary maneuver (i.e., a filibuster). Thus, the ability of the Senate or any controlling (but smaller than supermajority) faction to keep undesired items off of its agenda, i.e., to exercise

${ }^{1}$ Cox and McCubbins $(1993,1994)$ first introduced procedural cartel theory, but only in recent years have they focused explicitly on prefloor bill screening by majority party leaders (or negative agenda control) as the principal feature of the theory.

The Journal of Politics, Vol. 69, No. 3, August 2007, pp. 689-700 
negative agenda control, is generally considered to be quite limited (Smith, Roberts, and Vander Wielen 2006).

The canonical view of the two chambers, then, suggests that their respective levels of negative agenda control are quite different. ${ }^{2}$ Specifically, the Senate majority party should be less able to keep items off the agenda relative to the House majority party, due mainly to the Senate's more minimalistic (and minority-party friendly) institutional structure and more permeable agenda.

Challenges to this standard view have emerged in recent years. Campbell, Cox, and McCubbins (2002) find that the rate at which a majority of the Senate majority opposes measures that pass is not especially sensitive to the ideological distance between the majority party median and the chamber median, a result consistent with Cox and McCubbins' Housebased cartel model. Conceptually, they suggest that a prefloor/floor agenda model may better fit the Senate environment, wherein the majority party protects committee-generated bills from nongermane amendments via tabling and recommital motions. ${ }^{3}$ Cox and McCubbins (2005), Crespin and Monroe (2005), and Den Hartog and Monroe (2006) further challenge the received wisdom on conceptual grounds, contending that the majority party in the Senate possesses institutional mechanisms to control or influence the agenda, such as legislative scheduling, "filling out the amendment tree," procedural motions, or simply (if necessary, but at present off the equilibrium path) changing the standing rules of the chamber. Moreover, Den Hartog and Monroe (2006) find evidence (in an analysis of four recent congresses) that the Senate majority party indeed acts cohesively on the floor to table nongermane amendments offered by the minority party, consistent with one strand of the revisionist wisdom.

None of these revisionist arguments goes so far as to contend that majority party negative agenda control in the Senate is quite as great as majority party negative agenda control in the House. Indeed, Cox and McCubbins (2005, 94-96) explicitly doubt that the institutional tools controlled by the Senate majority party are as potent as those controlled by the House majority party. Rather, these arguments present a view in which the Senate majority party could plausibly

\footnotetext{
${ }^{2}$ We use the terms "agenda control" and "agenda power" synonymously throughout the paper.

${ }^{3} \mathrm{~A}$ related literature uncovers evidence consistent with the notion of individual senators being pressured by party leaders to vote with the party. See Volden and Bergman (2006).
}

exert substantial negative agenda control, though not at a level matching the House.

We contend that much less is known about the extent of majority party negative agenda control in the Senate relative to the House, and that - though neither the conceptual nor empirical literatures on this topic are huge-the conceptual discussion has if anything gotten ahead of the empirical results. Thus, our goal in this paper is to understand the degree of negative agenda control exerted by the Senate majority party. We discuss and statistically test theoretical expectations of how majority party negative agenda control should respond to pressures from outside the majority party, such as chamber pivots or control of the House or presidency by the other party, for several legislative vehicles considered in the Senate. Further, we take the House as a "strong party" benchmark and make explicit statistical comparisons of majority party negative agenda control in the Senate to that in the House.

To this end, the paper proceeds as follows. In the next section, we discuss the data and measures that we rely on to explore majority party negative agenda control in the Senate. Following this, we examine negative agenda control exercised by the Senate majority party for three different legislative vehicles: Senateoriginated bills, confirmation votes, and conference committee reports. Next, we compare conditional and unconditional measures of majority party negative agenda control across the Senate and House. Our results in these sections suggest a degree of majority party negative agenda control in the Senate that is significantly greater than recognized or predicted in the literature; thus, we discuss types of explanations for this finding before concluding.

\section{Negative Agenda Control: Concept and Measurement}

To explore negative agenda power we focus on party "roll rates" (Cox and McCubbins 2002, 2005). As noted, negative agenda power focuses on a party's ability to keep bills off the floor that a majority of its members dislikes. ${ }^{4}$ Such bills, ostensibly, would replace status quo policies with alternatives that are less

\footnotetext{
${ }^{4} \mathrm{~A}$ complementary question is whether parties can push collective choices away from the chamber median, conditional on considering an issue. Lawrence, Maltzman, and Smith (2006) answer in the affirmative, relying on evidence from "win rates." Win rates measure how often a group (to wit, the majority party) is on the winning side of a sequence of roll-call votes. If majority parties exert negative agenda control, they will block issues on which they "lose," thereby raising measured win rates.
} 
TABle 1 Majority Party Roll Rates, 45th through 106th Congresses (1877-2000)

\begin{tabular}{lcccccc}
\hline & \multicolumn{3}{c}{ Senate } & & \multicolumn{2}{c}{ House } \\
\cline { 2 - 4 } \cline { 6 - 7 } Roll Rate (\%) & S Bills & Conference Reports & Confirmation Votes & & HR Bills & Conference Reports \\
\hline Per-Congress Average & 5.5 & 3.9 & 10.2 & & 4.2 & 4.1 \\
Series Average & 3.3 & 3.4 & 9.2 & & 2.5 & 2.1 \\
No. of Congresses & 62 & 61 & 52 & 62 & 62 \\
No. of Final-Passage Votes & 1209 & 774 & 707 & & 3804 & 1417 \\
\hline
\end{tabular}

preferred by a majority of the party. When a majority of the majority party opposes a bill on the floor, but it nonetheless passes, the majority party is said to have been "rolled." A majority party roll rate in a Congress is then just the ratio of majority party rolls to finalpassage votes in that Congress. Roll rates can thus be thought of as an empirical marker of negative agenda control, in that rolls are observed "failures" of the party to successfully stop measures that its membership opposed. If the majority party is truly able to "veto" potential agenda items at the prefloor stageor, alternatively, to prevent prefloor decisions from being compromised via some floor-based mechanism or behavior - then majority rolls should be infrequent (or nonexistent). Negative agenda power should thus be correlated with majority party roll rates.

Roll rates are of course not a perfect measure of the unobservable construct of negative agenda control. They are subject to several critiques (e.g., Krehbiel 2007) which can be grouped into two broad categories. First, they are not isomorphic to negative agenda power: distributions of party ideal points, party caucus sizes, party leaders' decisions to press for marginal bills, and consideration of "trivial" versus "important" bills (from the perspective of the party leadership) may arguably all effect roll rates. Second, roll rates may provide only an upper bound measure of negative agenda power: e.g., because they are based (in our analysis) on final passage votes (which the majority may avoid when it expects to lose).

However, our use of roll rates, which is comparative and emphasizes responsiveness of roll rates to covariates, rather than their absolute levels, tends to vitiate these concerns. Obviously our analysis requires that roll rates are correlated with the underlying construct of negative agenda control, but even critics do not dispute this correlation (assuming agenda control exists). Beyond this, other factors that map into roll rates (e.g., the selection effect of final passage rotes) seem to apply regardless of which chamber of Congress one explores. While some conditions may differ on average across chambers (e.g., distributions of caucus sizes), this simply creates different baseline expectations for roll rates that will be reflected in intercepts of statistical models we estimate. Moreover, given that we compare the responsiveness of roll rates to covariates across chambers and legislative vehicles in linear models, differences in levels of those covariates (e.g., measures of preference distributions) in different models is relatively inconsequential. Thus, while circumspection about roll rates as a measure of the unobserved constrict of interest is appropriate, it must be put in context of our use of them.

We compile majority party roll rate data on all final-passage votes that elicited a roll call in the Senate from the 45th (1877-79) through 106th (1999-2000) Congresses. ${ }^{5}$ This interval is useful because it begins shortly before the rise of floor leadership in each chamber (Campbell, Cox, and McCubbins 2002; Cox and McCubbins 2005) and covers the postReconstruction period in congressional history, wherein the same two-party system has operated and politics have been regular (or reasonably so) across the entire time span. We examine roll rates on three different legislative vehicles: Senate-originated bills ( $\mathrm{S}$ bills), conference committee reports, and confirmation votes. These three categories provide important variation vis-à-vis negative agenda power, which we discuss at length in the next section.

Table 1 summarizes Senate roll rates, along with House roll rates on similar legislative vehicles (where applicable). The "per-Congress average" treats every Congress as an equally weighted observation. The "series average" is the ratio of rolls to final-passage votes on each vehicle, aggregating over the entire time span for both the numerator and denominator without regard to the Congress in which the vote occurred.

${ }^{5}$ Final-passage votes can change public policy and thus directly affect a member's utility, position taking, and reelection chances. Therefore, we (like Cox and McCubbins) use these votes to define roll rates. 
We present this information here to give a feel for majority party negative agenda control and postpone statistical comparisons until later in the paper. We note simply that, in general, majority party roll rates are "small" in the sense that 0 is a good prediction. Indeed, for most of the legislative vehicles, it is the modal result in the Senate across sessions of Congress. Furthermore, in a "naked eye" comparison, it does appear that Senate roll rates on a given legislative vehicle are generally greater than their relevant House counterparts: the per-Congress and series averages of $5.5 \%$ and $3.3 \%$ for chamber-originated bills in the Senate (S bills) exceed the $4.2 \%$ and $2.5 \%$ for chamber-originated bills in the House (HR bills); perCongress averages on conference reports are higher in the House ( $4.1 \%$ versus $3.9 \%)$, but the series average is greater in the Senate (3.4\% versus $2.1 \%){ }^{6}$ There is less here than meets the eye, however, as we address in more detail below. ${ }^{7}$

\section{Positive and Negative Agenda Control in the U.S. Senate}

In this section we analyze majority party negative agenda control in the Senate only, in isolation from the House. We analyze variation in roll rates, and their conditional expectations given covariates, on Senate-originated bills ( $\mathrm{S}$ bills), conference committee reports, and confirmation votes.

Theoretical expectations regarding majority party roll rates on these three legislative vehicles are based on the following observation: each legislative vehicle endows (by constitutional or procedural privilege) a specific actor besides the Senate majority party with some degree of positive agenda control on that vehicle, i.e., the ability to get something onto the legislative agenda and considered via a final-passage vote. On that specific legislative vehicle, this nonmajority party actor can secure consideration of its preferred choices. Even a Senate majority party with significant negative

\footnotetext{
${ }^{6}$ There is no counterpart to Senate confirmation votes in the House.

${ }^{7}$ Before turning to more detailed comparisons it is worth noting that the distributions of ideal points in both parties in the Senate (as measured by first-dimension DW-NOMINATE scores) have significantly greater standard deviations than in the House ( $p$-values in matched pairs $t$-tests are less than .01 for both parties). Thus it is immediately apparent that the low Senate roll rates are not reflecting an "easier case" of more homogenous majority parties than in the House. These comparisons, as well as all results in this paper, treat Southern Democrats the same as other Democrats.
}

agenda control would be unable to stop this. But if the Senate majority party otherwise restricts agenda access successfully, then on other legislative vehicles where a nonmajority party actor has no special privilege or proposal power, it should be unable to secure consideration of its preferred choices when opposed by the Senate majority.

To put it differently, if the Senate majority party restricts access to the Senate agenda in general, then disagreement with an actor will affect majority party roll rates only on legislative vehicles that require the Senate to respond to that actor. For other types of vehicles for which a specific actor is not privileged, a Senate majority party with negative agenda control will be able to hold off that actor's agenda advances. On the other hand, if the Senate agenda is generally permeable, and the majority does not restrict it, then disagreement with an actor will affect majority party roll rates for legislative vehicles besides the one that the actor in question "naturally" controls.

For example, the Senate's agenda on nominations (considered in confirmation votes) is set by the President. The nomination process (as established in the Constitution) confers some inherent positive agenda control on the President. Specifically, the nominees that the Senate faces, and on which roll rates are computed, are chosen by the President; the Senate majority itself has no formal positive agenda power over nominations. Moreover, when the President makes nominations, he must consider support in the Senate in general, but not specifically in the Senate majority party. For final confirmation, it does not matter which decisive coalition of Senators supports a nominee, as long as some decisive coalition does so. Therefore, a President at odds with the Senate majority party may select nominees that a majority of the Senate majority party does not prefer, but only because of a constitutional power that trumps party channels of negative agenda control. Even a Senate with majority party negative agenda control should experience higher roll rates on confirmations when it disagrees with the President. Operationally, since the Senate majority party cannot strictly control nominations, and cannot completely stop all of them, it can expect to be rolled more often on nominations under divided government than under unified government.

But does the President's agenda setting power extend into other legislative vehicles, like $S$ bills or conference reports, in which he possesses no formal privilege? If the Senate agenda is generally permeable, and the Senate majority party has little or no negative agenda power, the answer is yes. The President need 
only rely on or induce a like-minded Senator to "carry his water." In this case, Senate majority party disagreement with the President would increase roll rates in general, not just on the legislative vehicle for which the President has constitutionally guaranteed positive agenda power, because the President would be able to ensure consideration of measures the Senate majority party does not prefer (by assumption). But if the Senate majority party generally does possess negative agenda control on its own chamber business, the answer is no. In this case the Senate majority party would be able to prevent incursions into its own chamber business by the President, and Senate majority party disagreement with the President would increase roll rates on confirmation votes only.

Similarly, the conference-committee reports on which the Senate votes are fashioned in bargains with the House. The preferences of House conferees affect the substance of conference reports. Therefore, the House helps to determine the content of the items the Senate considers in this category, and this affects votes in the roll rate measure. This is not because the Senate majority lacks negative agenda control; rather, it is due to how conference committees operate. But the House does not have other formal prerogatives on the Senate agenda, so its positive agenda power with respect to the Senate should be confined to conference reports.

Finally, on Senate-originated bills, every Senator has some positive agenda power. Given the Senate's general lack of germaneness restrictions or ex ante limitations on debate, a Senator wishing to introduce an issue for consideration need only, to a first approximation, start talking. Under such an open agenda with majority or supermajority voting (given the cloture requirement that any considered bill must overcome), the preference of a legislator in the core of the voting rule (the median for simple majority rule, or generalized median for supermajority rule) on the issue under consideration can be taken as decisive. In this respect, the natural place to look for positive agenda control on $\mathrm{S}$ bills is the filibuster pivot closest to the majority party median. Among Senators whose disagreement with a measure is sufficient to halt consideration of it, this is the Senator most in ideological agreement with the majority of the majority party. If the majority party cannot count on even this pivotal Senator to oppose a measure, there would seem to be little the majority party can do to stop its consideration in the Senate.

In short, this typology of legislative vehicles suggests that some actor besides the Senate majority party has positive agenda control on a given legisla- tive vehicle. Critically for our purposes, this positive agenda control in turn implies a limit on the Senate majority party's negative agenda control. The reason is that an increase in positive agenda control for one actor necessarily implies a decrease in the negative agenda control of another. Positive agenda control, by definition, means that an actor's preference is sufficient to place its preferred items on the chamber's agenda. Negative agenda control, by definition, means that an actor's assent is necessary to place an item on the chamber's agenda. If actor $A$ acquires positive agenda control on a legislative vehicle, it must mean that actor $B$ 's assent is not necessary for consideration. Thus, when a nonmajority party actor's positive agenda control increases in a given situation, as the previous discussion implies is the case for these legislative vehicles, the majority party's negative agenda control decreases in that situation. This relationship, in turn, should show up in majority party roll rates.

We explored these outside-actor effects on the Senate majority party's negative agenda control via a series of regression models. The unit of analysis in these models is a single Congress, and the results are based on those Congresses between the 45th (187779) and 106th (1999-2000) in which the majority party plus the Vice President controlled the Senate outright (at least numerically). ${ }^{8}$ We estimate the conditional mean of the majority party roll rate for each legislative vehicle as a function of Senate majority party disagreement with the House, the President, and the Senate's filibuster pivot. ${ }^{9}$ Disagreements with the House and President, respectively, were operationalized in terms of majority party control and are captured by dummy variables ( 1 if divided-party control of each set of institutions, 0 if unified-party control). Disagreement between the Senate majority party and the relevant filibuster pivot is operationalized using NOMINATE scores (Poole and Rosenthal 1997, 2001), specifically as the absolute value of the difference between the first dimension DWNOMINATE scores of the median member of the majority party and the filibuster pivot. To avoid

${ }^{8}$ In three Congresses- the 54th (1895-97), 55th (1897-99), and 84th (1955-56) - the Senate majority party actually held only a plurality of seats and did not have a majority when the Vice President's vote was considered. Because this could create an unusually weak situation for the majority party, we estimated Senate roll rates without these Congresses included in the estimation sample.

${ }^{9}$ We also modeled each conditional mean as a function of the majority's disagreement with the chamber median, but found no substantively important effects. 
TABLE 2 Regression Results, Majority Party Roll Rates in the Senate, by Legislative Vehicle

\begin{tabular}{lccc}
\hline Explanatory Variable & S bills & Confirmation votes & Conference reports \\
\hline Majority party_Filibuster pivot distance & 29.28 & 56.33 & 1.02 \\
& $(35.95)$ & $(50.58)$ & $(15.65)$ \\
Senate-House divided government & -3.65 & 1.69 & $8.51^{\star * *}$ \\
& $(3.42)$ & $(4.58)$ & $(3.12)$ \\
Senate-President divided government & 2.60 & $24.53^{* * *}$ & -.79 \\
& $(3.70)$ & $(6.23)$ & $(2.57)$ \\
Time Trend & $-.22^{* * *}$ & -.08 & -.05 \\
& $(.07)$ & $(.10)$ & $(.07)$ \\
Constant & $18.47^{* * *}$ & 3.14 & 6.43 \\
& $(6.25)$ & $(8.85)$ & $(5.85)$ \\
F statistic (No. obs.) & $3.31^{* *}(59)$ & $5.82^{\star * *}(49)$ & $2.69^{* *}(58)$ \\
\hline
\end{tabular}

Note: Each column is a separate model of the Senate majority party roll rate. Entries are OLS estimates with Newey-West standard errors in parentheses. The filibuster pivot is the nearest legislator to the majority party median satisfying the pivot criterion given the cloture rules.

${ }^{\star}$ denotes significance at $\alpha=.10$ or less; ${ }^{* *}$ denotes .05 or less; ${ }^{* *}$ denotes .01 or less.

spurious associations due to trends, we also included a linear time trend. ${ }^{10}$

The results are based on ordinary least squares estimation; to avoid inference problems due to heteroskedasticity or serial correlation, ${ }^{11}$ we used NeweyWest (heteroskedasticity-autocorrelation consistent) standard errors. ${ }^{12}$ The OLS parameter estimates are presented in Table 2 with Newey-West standard errors in parentheses.

A word about the filibuster pivot in these models is in order. The critical filibuster pivot from the standpoint of majority party negative agenda control is the Senator closest to the majority party median whose opposition to a measure would sustain a filibuster, thereby keeping the chamber from acting on it. This is the "pivot of last resort" for the majority party: if all of its other negative agenda control tactics fail, it can at least mount a filibuster if it has the agreement of this

\footnotetext{
${ }^{10}$ Based on Dickey-Fuller tests, the time series of the dependent variable is difference stationary, but not trend stationary. Therefore, we include a time trend in the regressions and do not pursue first differencing or transformations appropriate for an integrated series.

${ }^{11}$ We allowed for second-order autocorrelation in the error term, e.g., in case of an election year effect. But first versus second order did not greatly affect the results.

${ }^{12}$ We obtained substantively similar conclusions (in particular, similar significance test results for each coefficient) from the Berkson-Cox smoothed logit estimator (Maddala 1983; this is the MLCS estimator used in Cox and McCubbins 2005), Tobit models for censored data (since about half the observations are leftcensored at 0), negative binomial regression models for the frequency of majority rolls in each Congress, and Prais-Winsten regression for serially correlated errors.
}

pivot. That the majority party does not often deploy this control tactic on the equilibrium path does not imply that it could not. The power to deploy this pivot of last resort, then, is a floor on majority party negative agenda control in a session of Congress. Under Democratic majorities when most members have negative DW-NOMINATE scores, this pivot is the Senator with the DW-NOMINATE score (first dimension) at the 40th percentile in Congresses after 1975 (with 60 votes needed for cloture), the 33rd percentile from 1917 to 1975 (with 67 votes needed for cloture), and the minimum position before 1917 (with 100 votes needed for cloture). ${ }^{13}$ Under Republican majorities, similarly, this pivot is the Senator at the 60th percentile, the 67th percentile, or the maximum position, depending on the cloture requirement.

Referring to column 1 of Table 2, it is notable that for S bills specifically, no external actor's disagreement with the Senate majority party is sufficient to jeopardize majority party negative agenda control. Despite the supposedly permeable Senate agenda, neither the filibuster pivot, nor the chamber median (whose effect, estimated in a different model not shown, is also insignificant), nor the House majority, nor the President have the ability to force items onto the Senate agenda to the Senate majority party's displeasure. Moreover, majority party negative agenda control has

\footnotetext{
${ }^{13}$ Here we depart from Wawro and Schickler's (2006) definition of the pre-1917 cloture pivot, though in our particular context this difference is relatively inconsequential.
} 
improved over time, as indicated by the negative and significant coefficient for the time trend. ${ }^{14}$

Looking across models (i.e., within rows across columns of Table 2), it is also notable that, with one exception, an actor's influence on majority party roll rates in the Senate is always greatest, and in the expected direction, for the legislative vehicle on which that actor has the greatest (formal) positive agenda control. Disagreement with the President matters most (indeed, only) for roll rates on confirmation votes. Disagreement with the House majority party matters most for conference reports. The exception is the effect of disagreement between the Senate majority party median and the filibuster pivot: the effect is greatest for confirmation votes; it is smaller for $\mathrm{S}$ bills. However, this is not a glaring exception because neither of these estimates is significantly different from 0 .

The side-by-side presentation of the estimated models invites comparisons of their parameter estimates for each variable. However, since parameter estimates are simply realizations of random variables, it is no more legitimate to make "naked eye" comparisons of them than it is to compare two population means by "eyeballing" the difference in means of samples drawn from them. As with any other comparison of population parameters based on realized random variables, an adequate comparison requires a hypothesis test. For model coefficients, we execute Wald $\left(\chi^{2}\right)$ tests to assess whether the effect of some covariate is systematically greater on roll rates for one legislative vehicle than another, by evaluating differences in parameter estimates across a given row of Table $2 .{ }^{15}$ These tests are based on each parameter estimate, its estimated variance, and its covariance with parameter estimates in other models. The null hypothesis in any

\footnotetext{
${ }^{14}$ It is unlikely that this result occurs simply because every senator has some degree of negative agenda control, e.g., because of filibuster threats or consensual norms (although it may be true that they do). The mean Senate minority party roll rate on S bills over the time period we study is $24.4 \%$, several multiples of the mean majority roll rate. Thus the minority party is much less effective than the majority at keeping unwanted items from the agenda, despite typically being a relatively large but coherent group. In addition, the House appears to be roughly as cohesive as the Senate in general: the average percentage of yea votes on final passage across Congresses in our sample is $79.8 \%$ for the $S$ bills in the Senate, and $79 \%$ for HR bills in the House. These findings suggest that the apparent effectiveness of the Senate majority is not merely the result of widespread and generalized negative agenda power in the Senate.

${ }^{15}$ For a treatment emphasizing the importance of significance testing when comparing different parameter estimates, as well as the pitfalls of simple comparisons of significance levels, see Gelman and Stern (2006).
}

such test is that the coefficient on a given variable is identical across two models. In each test the alternative is two-sided.

Consider the first row of table 2, reflecting the effect of disagreement between the Senate majority party and the filibuster pivot on roll rates. The difference between the marginal effects on S-bill and confirmation-vote roll rates (marginal effects are 29.28 and 56.33, respectively) and conference-report roll rates (marginal effect is 1.02) is quite large. Nevertheless, these differences are not nearly significant at conventional levels in any pairwise comparison across models. For example, the $p$-value in a comparison of conference report and confirmation vote model coefficients is about 28 .

On the other hand, moving to row 2 of table 2, disagreement between the Senate and House does have a significantly greater effect on conference-report roll rates (marginal effect is 8.51) than on $S$ bill roll rates (marginal effect is -3.65). ${ }^{16}$ The $p$-value in a test of no difference in these effects is .07. Further, examining row 3 of Table 3 shows that disagreement between the Senate and President has a much larger effect on confirmation-vote roll rates (marginal effect is 24.53) than on other legislative vehicles (marginal effect is 2.60 for S bills, -.79 for conference reports), and this difference is significant at the .01 level in each case. ${ }^{17}$

In sum, the reduction in the Senate majority party's negative agenda power because of disagreement with some other actor tends to be greatest for legislative vehicles on which that other actor necessarily (either by the Constitution or the conventional interpretation of standing Senate rules) has some positive agenda power. If that actor's effect on majority party negative agenda power is significant in the first place, it tends to be significantly lower on legislative vehicles over which the actor has no institutional assurance of positive agenda control. Based on the theoretical discussion at the beginning of this section, this is the pattern one would expect in roll rates if the Senate majority party does indeed exert negative

\footnotetext{
${ }^{16}$ There are several specific reasons why this may occur. The chamber leadership may be constrained by public opinion to allow consideration of a bill, and the conference under Senate-House divided government may require some compromise that Senate majority party members dislike. Moreover, some of the effect may arise from cases when the Senate is divided from both the House and the President. In that case the Senate faces an extra source of pressure that may induce it to act. We find a similar effect of Senate-House divided government on the House majority conference report roll rate, as reported below.
}

${ }^{17}$ Campbell, Cox, and McCubbins (2002) note a similar result in a comparison of roll rates on $\mathrm{S}$ bills and confirmation votes. 
TABLE 3 Regression Results, Majority Party Roll Rates in the Senate and House, by Legislative Vehicle

\begin{tabular}{|c|c|c|c|c|c|c|}
\hline Explanatory Variable & $\begin{array}{c}\text { Senate } S \\
\text { bills }\end{array}$ & $\begin{array}{c}\text { House } \\
\text { HR bills }\end{array}$ & $\begin{array}{c}\text { Wald test } \\
\text { stat. ( } p \text {-val. })\end{array}$ & $\begin{array}{l}\text { Senate } \\
\text { conference } \\
\text { reports }\end{array}$ & $\begin{array}{l}\text { House } \\
\text { conference } \\
\text { reports }\end{array}$ & $\begin{array}{l}\text { Wald test stat. } \\
\quad(p \text {-val. })\end{array}$ \\
\hline $\begin{array}{l}\text { Majority party—pivot } \\
\text { distance }\end{array}$ & $\begin{array}{c}29.28 \\
(35.95)\end{array}$ & $\begin{array}{r}20.31^{*} \\
(10.43)\end{array}$ & $\begin{array}{l}.06 \\
(.80)\end{array}$ & $\begin{array}{c}1.02 \\
(15.65)\end{array}$ & $\begin{array}{c}13.82 \\
(11.99)\end{array}$ & $\begin{array}{l}.55 \\
(.46)\end{array}$ \\
\hline $\begin{array}{l}\text { Senate-House divided } \\
\text { govt. }\end{array}$ & $\begin{array}{l}-3.65 \\
(3.42)\end{array}$ & $\begin{array}{r}5.71^{\star} \\
(3.02)\end{array}$ & $\begin{array}{l}3.34^{*} \\
(.07)\end{array}$ & $\begin{array}{l}8.51^{\star * *} \\
(3.12)\end{array}$ & $\begin{array}{l}10.28^{\star \star} \\
(3.92)\end{array}$ & $\begin{array}{l}.10 \\
(.75)\end{array}$ \\
\hline $\begin{array}{l}\text { Chamber-President } \\
\text { divided govt. }\end{array}$ & $\begin{array}{c}2.60 \\
(3.70)\end{array}$ & $\begin{array}{c}-1.77 \\
(1.97)\end{array}$ & $\begin{array}{l}1.44 \\
(.23)\end{array}$ & $\begin{array}{l}-.79 \\
(2.57)\end{array}$ & $\begin{array}{l}-3.58 \\
(2.41)\end{array}$ & $\begin{array}{l}1.68 \\
(.19)\end{array}$ \\
\hline Time Trend & $\begin{array}{l}-.22^{\star * \star} \\
(.07)\end{array}$ & $\begin{array}{l}-.16^{\star * \star} \\
(.04)\end{array}$ & $\begin{array}{l}.39 \\
(.55)\end{array}$ & $\begin{array}{c}-.05 \\
(.07)\end{array}$ & $\begin{array}{c}-.06 \\
(.06)\end{array}$ & $\begin{array}{l}.02 \\
(.88)\end{array}$ \\
\hline Constant & $\begin{array}{l}18.47^{\star * *} \\
(6.25)\end{array}$ & $\begin{array}{l}12.65^{\star * *} \\
(3.00)\end{array}$ & $\begin{array}{l}.62 \\
(.43)\end{array}$ & $\begin{array}{c}6.43 \\
(5.85)\end{array}$ & $\begin{array}{c}5.77 \\
(4.88)\end{array}$ & $\begin{array}{l}.01 \\
(.90)\end{array}$ \\
\hline F statistic (No. obs.) & $\begin{array}{l}3.31^{* *} \\
(59)\end{array}$ & $\begin{array}{l}4.61^{* * *} \\
(62)\end{array}$ & & $\begin{array}{l}2.69^{* *} \\
(58)\end{array}$ & $\begin{array}{l}2.23^{*} \\
(62)\end{array}$ & \\
\hline
\end{tabular}

Note: Columns are separate models of the Senate or House majority party roll rate.

Entries are OLS estimates with Newey-West standard errors in parentheses. The pivot in Senate models is the nearest legislator to the majority party median satisfying the pivot criterion given the cloture rules. The pivot in the House models is the chamber median.

For tests that individual coefficients are different from $0,{ }^{*}$ denotes significance at $\alpha=.10$ or less; ${ }^{* *}$ denotes .05 or less; ${ }^{* *}$ denotes .01 or less.

Wald $\left(\chi^{2}\right)$ statistics are from tests for difference in model coefficients across columns, with two-tailed $p$-values (not standard errors) in parentheses.

agenda control. It is different from the pattern one would expect if the Senate agenda were generally permeable, and the Senate majority were unable to keep unwanted measures off of it.

These findings suggest that the majority party in the Senate is able to exercise negative agenda control. But how strong is the Senate majority party's negative agenda control in a relative sense? One way to determine how the Senate majority party's negative agenda control stacks up is to compare it with a benchmark known to have significant channels of party strength and negative agenda control. The House furnishes such a benchmark, and we explore it in the next section.

\section{Negative Agenda Control in the Senate and the House}

Of the legislative vehicles we consider above, two also appear in the House: conference reports and chamberoriginated bills ( $\mathrm{HR}$ bills in the House being the natural analogue to $S$ bills in the Senate). A straightforward way to determine whether majority party negative agenda control in the House is greater than majority party negative agenda control in the Senate is to compare roll rates on these vehicles across chambers. Furthermore, since the House is often taken as a "strong party" case in the United States, this comparison allows us to benchmark Senate majority party strength in broader terms.

We first explore unconditional roll rates, not their responsiveness to nonmajority party actors. Comparing majority party roll rates by Congress (cf. Table 1), the House-Senate differences are neither large nor statistically significant for either chamber-originated bills ( $p$-value in two-tailed $t$-test for difference in means is $.50)$ or conference reports ( $p$-value is .92). On the other hand, House-Senate differences in each series as a whole are closer to being statistically distinguishable. The difference between the Senate majority party roll rate on S bills (3.3\% in 1209 final-passage votes) and the House majority party roll rate on HR bills $(2.5 \%$ in 3804 final-passage votes) is borderline significant ( $p$-value in two-tailed $z$-test for difference in proportions is .116), as is the difference in majority party roll rates on conference reports ( $p$-value is .078). ${ }^{18}$

In any case, the differences in unconditional majority party roll rates are not large from a substan-

\footnotetext{
${ }^{18}$ The comparison of per-Congress average roll rates is more appropriate than the comparison of the entire series if the important variation in party power in a chamber is considered to be Congress-by-Congress rather than bill-by-bill or vote-by-vote. Arguably, this is the case. Nevertheless, the per-Congress average treats as equally weighted two different Congresses with very different numbers of final passage votes.
} 
tive point of view, measured either in terms of a perCongress average or over the entire data series. In the Senate as well the House, the best guess about a finalpassage vote on a chamber-originated bill opposed by a majority of the majority party is overwhelmingly that it will fail to pass. Given the stronger institutional advantages afforded to the majority party in the House to control the legislative agenda, ${ }^{19}$ these small substantive differences are somewhat surprising. Thus, unconditional on covariates and on a purely descriptive level, the fingerprints of negative party power are apparent in the Senate, despite the absence of a clear theory or obvious mechanisms.

Prior roll rate results reported by Cox and McCubbins $(2005,94)-6 \%$ for the Senate versus $2.5 \%$ for the House for the post-Reconstruction series of Congresses through the 105th-seem to contradict our claim that the substantive differences are not large. But they in fact do not. Cox and McCubbins combine rolls on Senate-originated bills and confirmation votes. But, as we showed in Table 1 earlier, roll rates on confirmations are much greater than on S bills (10.2\% versus $5.5 \%$ on average in the 45th through 106th Congresses; $9.2 \%$ versus $3.3 \%$ over the whole series of votes). In other words, it is only confirmation votes, which have no obvious House analogue, that make the Senate majority party appear less powerful in negative terms than the House. When roll rates are disaggregated, and compared across chambers on comparable legislative vehicles (chamber bills and conference reports), the observed differences across chambers are not unlike those expected from nonsystematic random variation.

These unconditional comparisons reveal some similarity between aggregate roll rates in the Senate and House. Yet as noted in the previous section, some of the most important claims about negative agenda control by majority parties relate to their conditional behavior, not their unconditional levels. As we demonstrate below, this responsiveness to a given nonmajority party actor generally does not differ significantly across chambers. This can be seen in regression models for each legislative vehicle in each chamber. Table 3 reports results from these models for House majority party roll rates on HR bills and on conference reports.

These models are like those in Table 2 for the Senate, and the analogous models for Senate roll rates

\footnotetext{
${ }^{19}$ But see Crombez, Groseclose, and Krehbiel (2006) for an argument that institutions to support "gatekeeping" as a form of negative agenda control should be rare, and therefore differences across the chambers should be small (although, on their argument, the reason is that there is no negative agenda control).
}

on the legislative vehicles are presented as well for ease of comparison. The one difference between the House and Senate models for a given legislative vehicle is the relevant pivot: for the Senate, the filibuster pivot nearest the majority party median, as above; for the House, the chamber median. ${ }^{20}$ These models all use the OLS estimator with Newey-West standard errors robust to serial correlation up to the second order (and heteroskedasticity). ${ }^{21}$ The models for the House are estimated based on all Congresses between the 45th and 106th.

These models allow comparisons of the responsiveness of majority party negative agenda control to nonmajority party factors across the Senate and House. As with the models in Table 2, these comparisons are formalized in hypothesis tests that the coefficients on a given covariate are equal across chambers (i.e., across adjacent columns within a given row). The test statistics from these Wald $\left(\chi^{2}\right)$ tests and associated $p$-values (two-tailed) under the null hypothesis of equal coefficients are shown in the Wald test columns of Table 3.

First consider chamber-originated bills ( $\mathrm{S}$ bills and HR bills). The most notable result is that the effect of the majority party's distance from the relevant chamber pivot (filibuster pivot in the Senate, chamber median in the House) on majority party negative agenda control is similar and statistically indistinguishable across chambers. Indeed, the $p$-value in a test of the null hypothesis that these coefficients are

\footnotetext{
${ }^{20}$ Since the House and Senate models in Table 3 have regressors for different pivots - the chamber median in the House, the filibuster pivot in the Senate-a possible concern is that they are ideally suited for comparison because they do not have equivalent regressors. However, we also estimated fully comparable models with identical regressors, as well as models for the Senate with both the chamber median and filibuster pivot as regressors (but only the chamber median in the House equation). These results, contained in the online appendix at http://journalofpolitics.org/articles.html, show that none of our conclusions depend on the differences between the models reported in Table 3. ${ }^{21}$ As for the Senate roll rate models, we explored the robustness of
these House specifications, in terms of signs and statistical signifi-
cance of effects, with a variety of other estimators, specifically
Prais-Winsten (GLS) regression for serially correlated errors, nega-
tive binomial regression for the frequency of rolls by Congress,
Tobit models for censored dependent variables, and Berkson-Cox
smoothed logit regression (also useful for censored dependent
variables). The crucial factor supporting the rather small p-value
of the "Majority Party-Chamber Median distance" variable in the
regression for HR bills is the linear time trend. Without this vari-
able, which is positively correlated with the pivot distance and
negatively correlated with majority roll rates on HR bills, the
distance between party and chamber median typically becomes
insignificant (but is still always positive).
} 
equal is $.80 .^{22}$ Likewise, the effects of the linear time trend, and of disagreement between the chamber majority and the President, are statistically indistinguishable across chambers. The sole significant difference in the effects of covariates on majority party roll rates across chambers is from disagreement with the majority party of the other chamber. In the Senate this disagreement has had a statistically insignificant effect on the majority party's negative agenda control in post-Reconstruction history. It was in the House that this disagreement significantly attenuated majority party negative agenda control to a politically important extent. Further, the effect in the House is significantly greater than the effect in the Senate (two-tailed $p$-value in Wald test of equal coefficients is .07).

When it comes to negative agenda control on conference reports, the differences in Senate and House majority party power are even smaller. In fact, not a single marginal effect in the Senate conference report model is nearly significantly different from the corresponding marginal effect in the House conference report model. ${ }^{23}$

Overall the evidence is strongly consistent with the contention that the chamber majority roll rates respond very similarly to external factors. Out of 10 tests for difference in coefficients in Table 3, only one is significant at the $\alpha=.10$ level—which happens to be the expected number of Type I errors in 10 tests. The most important point in these comparisons is that the majority party in the Senate does not lose more negative agenda power than the majority party in the House, as a result of increased conflict between the majority party and critical nonpartisan actors. Despite a seemingly more permeable agenda in the Senate and relatively clearer and stronger mechanisms of agenda

\footnotetext{
${ }^{22}$ Since Reed's Rules had such a profound effect on House majority-party power, we also estimated the models in Table 3 , and performed cross-model hypothesis tests, with a dummy variable for Congresses in which Reed's Rules were in force. This variable has a very significant and positive effect on House majority-party negative agenda control and slightly lowers the effect of the majority-chamber median distance. It has an insignificant effect in the Senate, as it should (cf. Cox and McCubbins 2005, chapter 4). However, the dummy does not have enough effect on the House model to change any of the pairwise comparisons of coefficients reported here.

${ }^{23}$ Note also that for conference reports, the conventional hypothesis test that the coefficient is 0 has the same qualitative result for all covariates in the Senate and House models. However, this fact is less crucial for comparing the chambers than evaluating whether the coefficients across models are different from each other. The reason is that two coefficients can have different results in a hypothesis test against 0 , even if they are actually identical to each other.
}

control in the House, the Senate majority party is not apparently much worse off for it in terms of restricting the agenda.

\section{Why Are Senate Majority Parties So Powerful?}

The conventional wisdom that Senate majority parties are less muscle-bound than their brawny House counterparts has been under revision for several years. Campbell, Cox, and McCubbins (2002); Bargen (2004); Cox and McCubbins (2005); Crespin and Monroe (2005); Patty (2006); and Den Hartog and Monroe (2006) all challenge this wisdom conceptually and to some extent empirically. These scholars all argue that the Senate majority party is more powerful than conventional wisdom would have it.

But even proponents of partisan theories of the Senate do not go so far as to claim that the majority party's negative agenda control in the Senate should match that of the House in substantive terms. Instead, they point to mechanisms in the Senate that could plausibly confer some negative agenda power on the Senate majority party, while still acknowledging that the Senate agenda is more open than the House agenda, is less subject to extremely tight control, and is more likely to be buffeted by nonpartisan factors than the House agenda-because of filibusters, minority obstructionism, individualistic norms, etc. In short, the coalescing theoretical agreement is that majority party negative agenda control in the Senate is plausibly greater than the received wisdom recognizes, but tolerates weaknesses in majority party agenda control in the Senate relative to the House.

Two categories of explanation can account for the observed similarity in majority party negative agenda control across the two chambers of Congress. First, it is possible that the Senate and House have unique features, different from each other, that nevertheless both serve the end of party power. To explain negative agenda control in the Senate and yet maintain consistency with the explanations detailed for the House, it is necessary to find Senate-specific institutions, features, and practices that also confer negative agenda power on the Senate majority party. For example, Campbell, Cox, and McCubbins (2002) suggest that the Senate majority party may act as a floor voting coalition, to partially overcome the lack of prefloor screening mechanisms comparable to those in the House. Den Hartog and Monroe (2006) suggest the concept of "home field advantage" to account for Senate majority party strength. 
Second, it is possible that the Senate and House have features, practices, and institutions in common with each other that support party power similarly in each institution. One simple example not explored in the literature is the social psychological basis of party power. It is well known in social psychology (e.g., from the famous "robber's cave" experiment) that even arbitrary (and per force self-selected) groupings of individuals into "teams" can dramatically affect their behavior, especially cohesiveness, cooperation, and mutual support (e.g., Bornstein and Rapoport 1982; Kramer and Brewer 1984; Sherif et al. 1961). This sort of explanation would account for the similarity in party power across legislative chambers with relatively different internal institutions. Obviously, however, any such approach runs against the grain of contemporary research on parties-in-legislatures, as it deflects attention from the party-supporting institutions of the House specifically. Concretely, such an approach could not explain the effect of, for example, Reed's Rules in the House and their simultaneous lack of effect in the Senate. This type of approach is also so poorly developed that examples from the literature are not readily available.

A broader theory of the underpinnings of majority party power in Congress might also provide important insights into commonalities of party effects in the Senate and the House. Central to procedural cartel theory is the notion that all members of the majority party agree to the "cartelization" of the agenda. This includes the moderate members of the majority party, many of whom have to vote against their own policy interests to support their party. Cox and McCubbins (2005, 47-48) stress the distributive benefits that centrist members of the caucus can receive, such as campaign funds, committee assignments, even larger offices, to compensate for their policy losses. The literature is unclear on whether such a quid pro quo takes place with moderate caucus members, but it would help to explain the basis of party power that also has policy consequences.

\section{Conclusion}

This paper presents two related findings. First, roll rates for the Senate majority party on alternative legislative vehicles respond to pressures from nonmajority party actors, as one would expect if the Senate majority party exerts significant negative agenda control. Roll rates do not respond as one would expect if the Senate majority party were incapable of keeping unwanted items from being considered by the chamber. Second, and even more surprisingly, the response of roll rates in the Senate to these factors is typically indistinguishable, in statistical terms, from the response of majority roll rates in the House of Representatives to comparable factors. These findings are based on majority party roll rates on chamberoriginated bills, confirmation votes, and conference committee reports from the end of Reconstruction to the end of the twentieth century.

These conclusions are informative about Senate majority party power because the House of Representatives is the best "strong party" benchmark available in the United States. A large literature has explicated the channels of majority party power in the House, while the Senate has traditionally been thought to provide much more meager channels of party power. Even recent research more sanguine about prospects for majority party power in the Senate has explicitly stopped short of putting it on par with the House majority caucus. Our findings demonstrate that, in terms of keeping unwanted measures from receiving floor consideration, the Senate majority party is no less successful than the House majority party when it faces disagreement from some nonmajority party actor.

Thus, there is reason to be sanguine about Senate majority party power, though it is if anything stronger than recent research on parties in the Senate seems to allow or imply. Our account in this paper can make sense of variation in roll rate behavior across legislative vehicles within the Senate, because this variation is consistent with negative agenda power for the Senate majority party. Yet it remains an open issue for further research to make sense of the similarity in roll rate behavior on a given legislative vehicles across the two chambers of Congress.

\section{Acknowledgments}

An earlier version of this paper was presented at the Conference on Party Effects in the U.S. Senate, Duke University. We thank Andrea Campbell, Mathew McCubbins, Nathan Monroe, and David Rohde for access to various Senate and House data sets used in this analysis, and Chuck Finocchiaro, Frances Lee, John Patty, and Howard Rosenthal for detailed comments on a previous draft. Finally, we greatly benefited from several discussions with Chris Den Hartog and Nathan Monroe on the subject of party power in the Senate.

Manuscript submitted 19 June 2006

Manuscript accepted for publication 16 October 2006 


\section{References}

Aldrich, John. 1995. Why Parties? The Origin and Transformation of Political Parties in America. Chicago: University of Chicago Press.

Bargen, Andrew. 2004. "Party Power in the U.S. Senate: Shaping the Ideological Content of the Legislative Agenda," Presented at the annual meeting of the American Political Science Association.

Bornstein, Gary, and Anatol Rapoport 1982. "Intergroup Competition for the Provision of Step-Level Public Goods: Effects of Preplay Communication." European Journal of Social Psychology 18 (2): 125-42.

Campbell, Andrea C., Gary W. Cox, and Mathew D. McCubbins. 2002. "Agenda Power in the U.S. Senate, 1877-1986." In Party Process and Political Change in Congress: New Perspectives on the History of Congress, ed. David W. Brady and Mathew D. McCubbins. Stanford, CA: Stanford University Press, pp. 14665.

Cox, Gary W., and Mathew D. McCubbins. 1993. Legislative Leviathan: Party Government in the House. Berkeley: University of California Press.

Cox, Gary W., and Mathew D. McCubbins. 1994. "Bonding, Structure, and the Stability of Political Parties: Party Government in the House." Legislative Studies Quarterly 19 (2): 215-31.

Cox, Gary W., and Mathew D. McCubbins. 2002. "Agenda Power in the U.S. House of Representatives, 1877-1986." In Party Process and Political Change in Congress: New Perspectives on the History of Congress, ed. David W. Brady and Mathew D. McCubbins. Stanford, CA: Stanford University Press, pp. 107-45.

Cox, Gary W., and Mathew D. McCubbins. 2005. Setting the Agenda: Responsible Party Government in the U.S. House of Representatives. Cambridge: Cambridge University Press.

Crespin, Michael H., and Nathan W. Monroe. 2005. "Party Agenda Control in the Senate: A Preliminary Hearing." Typescript. Michigan State University.

Crombez, Christophe, Tim Groseclose, and Keith Krehbiel. 2006. “Gatekeeping." Journal of Politics 68 (2): 322-34.

Den Hartog, Chris, and Nathan M. Monroe. 2006. "Home Field Advantage: An Asymmetric-Cost Theory of Legislative Agenda Influence in the U.S. Senate." Typescript. Michigan State University.

Gelman, Andrew, and Hal Stern. 2006. "The Difference Between 'Significant' and 'Not Significant' is Not Itself Statistically Significant." The American Statistician 60 (4): 328-31.
Kramer, R. M., and M. B. Brewer. 1984. "Effects of Group Identity on Resource Use in a Simulated Commons Dilemma." Journal of Personality and Social Psychology 46 (5): 1044-56.

Krehbiel, Keith. 2007. "Partisan Roll Rates in a Nonpartisan Legislature." Journal of Law, Economics, and Organization 23 (1): $1-23$.

Lawrence, Eric, Forest Maltzman, and Steven Smith. 2006. "Who Wins? Party Effects in Legislative Voting." Legislative Studies Quarterly 31 (1): 33-70.

Maddala, G. S. 1983. Limited-Dependent and Qualitative Variables in Econometrics. New York: Cambridge University Press.

Oleszek, Walter J. 2004. Congressional Procedures and the Policy Process. 6th ed. Washington: CQ Press.

Patty, John. 2006. "Equilibrium Party Government.” Typescript. Harvard University.

Poole, Keith T., and Howard Rosenthal. 1997. Congress: A PoliticalEconomic History of Roll Call Voting. New York: Oxford University Press.

Poole, Keith T., and Howard Rosenthal. 2001. "D-NOMINATE After Ten Years: A Comparative Update to Congress: A PoliticalEconomic History of Roll Call Voting." Legislative Studies Quarterly 26 (1): 5-31.

Rohde, David W. 1991. Parties and Leaders in the Postreform House. Chicago: University of Chicago Press.

Sherif, M., O. Harvey, B. White, W. Hood, and C. Sherif. 1961. Intergroup Conflict and Cooperation: The Robber's Cave Experiment. Norman: University of Oklahoma Press.

Smith, Steven S., Jason Roberts, and Ryan Vander Wielen. 2006. The American Congress. Fourth Edition. New York: Cambridge University Press.

Volden, Craig, and Elizabeth Bergman. 2006. "How Strong Should Our Party Be? Party Member Preferences Over Party Cohesion." Legislative Studies Quarterly 31 (1): 71-104.

Wawro, Gregory, and Eric Schickler. 2006. Filibuster: Obstruction and Lawmaking the U.S. Senate. Princeton, NJ: Princeton University Press.

Sean Gailmard is assistant professor of political science, University of California, Berkeley, Berkeley, CA 94720. Jeffery A. Jenkins is associate professor of politics, University of Virginia, Charlottesville, VA 22904. 